\title{
APC Haploinsufficiency, but Not CTNNB1 or CDH1 Gene Mutations, Accounts for a Fraction of Familial Adenomatous Polyposis Patients Without APC Truncating Mutations
}

\author{
Tiziana Venesio, Antonella Balsamo, Marco Rondo-Spaudo, Liliana Varesco, \\ Mauro Risio, and Guglielmina Nadia Ranzani
}

Unit of Pathology (TV, AB, MR), Institute for Cancer Research and Treatment, Candiolo-Torino, and Department of Genetics and Microbiology (MR-S, GNR), University of Pavia, Pavia, and Unit of Cancer Genetics (LV), IST, Genova, Italy

SUMMARY: Familial adenomatous polyposis (FAP) is an autosomal dominant condition characterized by the development of hundreds to thousands of colorectal adenomatous polyps. In addition to the classic form, there is also attenuated polyposis (attenuated adenomatous polyposis coli; AAPC), which is characterized by a milder phenotype. FAP/AAPC is caused by germline mutations in the adenomatous polyposis coli $(A P C)$ gene. Very recently, germline mutations in the base-excision repair gene $M Y H$ have been associated with recessive inheritance of multiple colorectal adenomas in a subset of patients. APC pathogenic alterations are mostly ( $>95 \%$ ) represented by frameshift or nonsense mutations leading to the synthesis of a truncated protein. We identified 20 APC truncating mutation carriers out of 30 FAP/AAPC patients from different Italian kindreds. In the remaining 10 patients, we searched for alterations other than truncating mutations by enzymatic mutation detection, real-time quantitative RT-PCR, and genotyping of polymorphic markers encompassing the APC locus. Moreover, to assess whether mutations of genes interacting with $A P C$ can substitute or act in association with $A P C$ alterations, we sequenced both $C T N N B 1$ ( $\beta$-catenin) and CDH1 (E-cadherin) genes. No CTNNB1 or CDH1 mutations were found. On the contrary, four patients showed a reduced $A P C$ gene expression compared with healthy subjects. In three of the four cases, genotyping results were compatible with a constitutive allelic deletion. In one case this conclusion was confirmed by haplotype segregation analysis. Our results support the notion that FAP/AAPC can result from APC constitutive haploinsufficiency, with gene deletion being a possible cause of reduced gene expression. (Lab Invest 2003, 83:1859-1866).

$F$ amilial adenomatous polyposis (FAP) (OMIM $F_{175100)}$ is an autosomal dominant condition characterized by the development of hundreds to thousands of colorectal adenomatous polyps, conferring a very high risk of cancer at a young age. In addition to the classic form, there is also attenuated polyposis (attenuated adenomatous polyposis coli; AAPC), which is characterized by the development of fewer than 100 adenomas and delayed age of cancer onset (Friedl et al, 1996). Colorectal adenomas are the hallmark of FAP syndrome. However, in addition to polyps, affected individuals may also develop different clinical features, such as retinal lesions, desmoid tumors, and mandibular osteomas. Overall, patients with FAP show considerable phenotypic heterogene-

DOI: 10.1097/01.LAB.0000106722.37873.8D

Received June 10, 2003.

This work was supported by a COFIN-MIUR grant to GNR. MR-S was supported by a fellowship from the Fondazione Italiana per la Ricerca Sul Cancro. AB was supported by a fellowship from Ordine Mauriziano.

Address reprint requests to: Prof. G. N. Ranzani, Dip. Genetica e Microbiologia, Via Abbiategrasso 207, 27100 Pavia, Italy. E-mail: ranzani@ipvgen.unipv.it ity as exemplified by different number of adenomas, age of cancer onset, and extracolonic manifestations (reviewed in Vasen, 2000).

FAP is caused by germline mutations in the adenomatous polyposis coli (APC) tumor suppressor gene, localized on chromosome 5q21-22 (Groden et al, 1991; Kinzler et al, 1991). Pathogenic alterations are mostly ( $>95 \%$ ) represented by frameshift or nonsense mutations leading to the synthesis of a truncated protein (Laurent-Puig et al, 1998; Powell et al, 1993). Germline alterations are usually detected in $70 \%$ of classic patients with FAP and in $10 \%$ of patients with AAPC (Heinimann et al, 2001; Lamlum et al, 2000; Spirio et al, 1993; van der Luijt et al, 1996b). A genotype-phenotype correlation has been observed by several authors, suggesting that clinical variability partially depends on the position of mutations along the gene (reviewed in Fodde and Khan, 1995; Pilarski et al, 1999; Spirio et al, 1993; Varesco et al, 1994; van der Luijt et al, 1995).

Increasing evidence indicates that routinely used PCR-based molecular methods fail to detect APC mutations in $5 \%$ to $10 \%$ of patients and are inadequate for finding gene alterations such as large dele- 
tions or transcription defects (Laken et al, 1999; Mandl et al, 1996). There are a minority of patients who do not show detectable $A P C$ mutations even after intensive gene screening (Laken et al, 1999), suggesting the existence of additional susceptibility genes. Very recently, germline mutations in the base-excision-repair gene $M Y H$ have been associated with recessive inheritance of multiple colorectal adenomas in a subset of patients (Al-Tassan et al, 2002; Jones et al, 2002; Sieber et al, 2003).

APC has a gatekeeper role in colonic homeostasis. The protein plays a role in the Wnt signaling pathway by catalyzing the degradation of $\beta$-catenin (Munemitsu et al, 1995; Rubinfeld et al, 1996). As a consequence of APC inactivation, $\beta$-catenin accumulates in the cytoplasm and moves to the nucleus, where it mediates the transcription of Wnt target genes ( $\mathrm{He}$ et al, 1998; Tetsu and McCormick, 1999). $\beta$-catenin also plays a role in cell-cell adhesion by interacting with E-cadherin at the adherens junctions (Orsulic et al, 1999). Down-regulation of E-cadherin can be expected to shift $\beta$-catenin from adherens junctions to the cytoplasmic pool. However, no E-cadherin mutations have been demonstrated to directly increase $\beta$-catenin-dependent transcription of Wnt target genes (Suriano et al, 2003; van de Wetering et al, 2001; Wong and Gumbiner, 2003). On the other hand, reduction of $\mathrm{E}$-cadherin level has been shown to result in alterations of epithelial cell proliferation, migration, and apoptosis (Perry et al, 1999; Smits et al, 2000).

In this study we thoroughly investigated FAP/AAPC patients who tested negative for $A P C$ truncating mutations. We used different approaches to search for $A P C$ alterations other than chain-terminating mutations and to assess whether either $\beta$-catenin (CTNNB1) or E-cadherin (CDH1) gene mutations can substitute (or act in association with) $A P C$ alterations.

\section{Results}

Thirty individuals from different families proven to be affected by classic FAP (22 cases) or by AAPC (8 cases) were screened for APC-truncating mutations by protein truncation test (PTT). We identified 20 mutation carriers: 18 with classic polyposis $(18 / 22$ : $80 \%$ ) and 2 with AAPC (2/8: $25 \%$ ) ( $<<0.01$ by Fisher's exact test). Phenotype heterogeneity was observed among mutation carriers (data not shown) as well as among patients without truncating mutations (clinical and pathologic features are reported in Table 1).

The 10 patients without apparent mutation, including 6 cases of AAPC and 4 of classic FAP, were further investigated for germline mutations in $\beta$-catenin $(C T$ $N N B 1)$ and E-cadherin $(C D H 1)$ genes, as well as for $A P C$ gene alterations other than protein-truncating mutations. Regarding CTNNB1, we first sequenced the $5^{\prime}$ end (500 bp) of cDNA, where the majority of mutations occurring in sporadic colorectal cancer have been found (Samowitz et al, 1999). The remaining part of cDNA was divided into four fragments that were analyzed by the enzymatic mutation detection (EMD) assay. The $\mathrm{CDH1}$ gene was investigated by directly sequencing all exons, intron-exon boundaries, and the proximal promoter region. No CTNNB1 or CDH1 gene mutations were found.

To further investigate $A P C$, we sequenced 500 bp at the $5^{\prime}$ end of the cDNA. This was done to ensure that truncating mutations at the very 5 ' end of the coding region were not missed because of the running conditions we had used for PTT. We also searched for missense mutations along the entire coding region by means of the EMD assay. Neither missense nor truncating mutations at the very $5^{\prime}$ end of the gene were found. To assess APC transcription level in mutationnegative patients, we performed a real-time quantitative RT-PCR analysis. The 10 samples showed a relative quantity of $A P C$ cDNA ranging from 0.52 to 1.4. Samples expressing one only allele were expected to give values close to 0.5 . Accordingly, we considered patients who showed values from 0.52 to 0.64 (ie, Patients 1 to 4 in Table 2) as possible carriers of a nonfunctional allele.

To investigate whether a relatively lower mRNA level was compatible with a constitutive APC gene deletion,

Table 1. Clinical Characteristics of FAP/AAPC Patients Without APC Truncating Mutations

\begin{tabular}{|c|c|c|c|c|c|c|c|}
\hline $\begin{array}{c}\text { Patient } \\
\text { no. }\end{array}$ & $\begin{array}{l}\text { Sex/age at } \\
\text { diagnosis }\end{array}$ & $\begin{array}{l}\text { Number of } \\
\text { colon polyps }\end{array}$ & Histotype & $\begin{array}{l}\text { Size of } \\
\text { adenomas } \\
(\mathrm{mm})\end{array}$ & $\begin{array}{c}\text { Presence of } \\
\text { carcinomas/extracolonic } \\
\text { manifestations }\end{array}$ & $\begin{array}{l}\text { Family } \\
\text { history }\end{array}$ & Diagnosis \\
\hline 1 & $\mathrm{M} / 39$ & $>1000$ & Tub-Vill/LGD & $4-8$ & No/osteomas & Yes & FAP \\
\hline 2 & $F / 29$ & $>1000$ & Tub/LGD & $5-7$ & No/no & Yes & FAP \\
\hline 3 & $\mathrm{~F} / 65$ & $<70$ & Tub-Vill/LGD-HGD & $8-10$ & Yes/no & $?$ & AAPC \\
\hline 4 & $\mathrm{M} / 28$ & $>100$ & Tub/LGD & $2-5$ & No/no & Yes & FAP \\
\hline 5 & $\mathrm{~F} / 35$ & $<70$ & Tub/LGD & ND & No/no & $?$ & AAPC \\
\hline 6 & $\mathrm{~F} / 58$ & $<70$ & Tub/LGD & $<4$ & No/no & $?$ & AAPC \\
\hline 7 & $\mathrm{M} / 16$ & $<70^{a}$ & Tub/LGD & ND & No/no & Yes & AAPC \\
\hline 8 & $\mathrm{~F} / 51$ & $<70$ & Tub/LGD & $5-10$ & Yes/no & Yes & AAPC \\
\hline 9 & $\mathrm{M} / 40$ & $<70$ & Tub/LGD & ND & No/no & ? & AAPC \\
\hline 10 & $M / 29$ & $>100$ & Tub/LGD & $3-6$ & No/no & Yes & FAP \\
\hline
\end{tabular}

Tub, tubular; Vill, villous; LGD, low-grade dysplasia; HGD, high-grade dysplasia; ND, not determined.

${ }^{a}$ The father of this 16 -year-old patient showed $<70$ colon polyps at 45 years of age. 
Table 2. Real-Time Quantitative RT-PCR and Genotype Results for the 10 Patients Without APC-Truncating Mutations

\begin{tabular}{|c|c|c|c|c|c|c|c|c|c|}
\hline \multirow{2}{*}{$\begin{array}{c}\text { Patient } \\
\text { no. }\end{array}$} & \multirow[b]{2}{*}{ Diagnosis } & \multirow{2}{*}{$\begin{array}{c}\text { Relative } \\
\text { quantity of } \\
A P C \text { cDNA }\end{array}$} & \multicolumn{7}{|c|}{ Genotype } \\
\hline & & & Promoter & Ex11 & Ex15K & Ex15N & 3'-UTR & D5S346 & D5S656 \\
\hline 1 & FAP & 0.52 & Hom & Hom & Hom & Hom & Hom & Hom & Hom \\
\hline 2 & FAP & 0.60 & Hom & Hom & Hom & Hom & Hom & Het & Het \\
\hline 3 & AAPC & 0.60 & Hom & Hom & Hom & Hom & Hom & Hom & Het \\
\hline 4 & FAP & 0.64 & Het & Hom & ND & Het & Het & ND & ND \\
\hline 5 & AAPC & 0.80 & Het & Hom & Hom & Hom & Hom & Het & Het \\
\hline 6 & AAPC & 0.82 & Hom & Hom & Hom & Hom & Hom & Het & Het \\
\hline 7 & AAPC & 0.89 & Het & Het & ND & Het & Het & Het & Het \\
\hline 8 & AAPC & 1.07 & Het & Het & ND & Hom & Het & Het & Het \\
\hline 9 & AAPC & 1.25 & Het & Het & ND & Hom & Het & ND & ND \\
\hline 10 & FAP & 1.40 & Het & Het & ND & Het & Het & Het & Hom \\
\hline
\end{tabular}

Hom, homozygous; Het, heterozygous; ND, not determined.

patients were genotyped for polymorphic markers mapping at the $A P C$ locus. We analyzed five intragenic single nucleotide polymorphisms (SNPs), from the promoter to the $3^{\prime}$-untranslated region (UTR), as well as two polymorphic microsatellites at the 3 ' of the gene. All subjects retained heterozygosity at one or more intragenic markers, with the exception of four patients (Patients 1, 2, 3, and 6 in Table 2) who proved to be homozygous (suggesting hemizygosity) for all intragenic markers. Taking into account both quantitative RT-PCR and genotyping results, our findings suggest a constitutive APC allelic deletion causing haploinsufficiency in three patients (Patients 1, 2, and 3 in Table 2). For one FAP patient (Patient 1 in Table 2), we could confirm this hypothesis by family investigation: the proband and two affected nieces were apparently homozygous for all tested markers and were carriers of three different haplotypes (Fig. 1). Haplotype results can be explained by assuming hemizygosity at markers spanning the APC locus, consistent with a whole gene deletion cosegregating with FAP disease in the family. In other words, the three affected subjects do not share any haplotype, being carriers of the same allelic deletion encompassing the investigated markers.

\section{Discussion}

In this study we thoroughly investigated FAP/AAPC patients who tested negative for $A P C$-truncating mutations by searching for $A P C$ alterations other than protein truncations and by analyzing both CTNNB1 and $\mathrm{CDH} 1$ genes.

Because of their function and the relatively high mutation frequency in sporadic gastrointestinal tumors (Becker et al, 1994; Samowitz et al, 1999), the CTNNB1 and CDH1 genes can be regarded as possible candidates in predisposition to colorectal cancer. Most of the previous studies on CTNNB1 in FAP patients have been performed by analyzing only exon 3 (Cao et al, 1999; Muller et al, 1998), where the majority of somatic mutations have been found to occur in colorectal cancer (Samowitz et al, 1999). However, it is conceivable that these mutations, deeply impairing $\beta$-catenin function, are not tolerated at the constitutive level. We extended the analysis to the entire CTNNB1 gene, including sites coding for competitive binding of APC, E-cadherin, and TCF4/ LEF-1 to $\beta$-catenin. However, similarly to other authors (Dobbie and Muller, 1999), we could not find any mutation. The same result was obtained for the $\mathrm{CDH} 1$ gene. To the best of our knowledge, this is the first analysis of the gene in FAP/AAPC kindreds. Up to now, the strongest evidence to support a causal role for E-cadherin alterations in cancer predisposition is still the finding that $\mathrm{CDH} 1$ mutations are linked to the hereditary diffuse gastric cancer syndrome (Guilford et al, 1998). Moreover, Smits et al (2000) have demonstrated that constitutive $A p c$ and E-cadherin gene mutations are synergistic in intestinal tumor initiation in mice, indicating that $E$-cadherin mutations enhance $A P C$-driven tumors without affecting tumor progression. In FAP/AAPC patients with no detectable APCtruncating mutations, we also analyzed $A P C$ by both EMD and real-time quantitative RT-PCR methods. We observed deficiencies in gene expression in 4 of 10 subjects. Our results on polymorphic markers encompassing the APC locus were compatible with a constitutive allelic deletion in three of the four subjects. Whole gene deletion was supported by pedigree and haplotype analysis in one of these patients, although not proven at the molecular level.

We also found one patient with low APC gene expression who retains heterozygosity at the intragenic markers. This patient is likely to be carrier of a mutation within the APC locus. However, the precise nature of this $A P C$ defect may be difficult to define because Yan et al (2002) reported that in one FAP patient with a reduced expression of $A P C$, the entire coding region, as well as the $3^{\prime}-$ UTR and promoter, were completely normal.

Sieber et al (2002) have recently developed an assay on genomic DNA to detect APC deletions. With this approach, 7 (12\%) of 60 classic FAP and 0 of 143 AAPC patients without apparent $A P C$ mutations proved to carry a full gene deletion. These patients were from different European origin. No deletions 


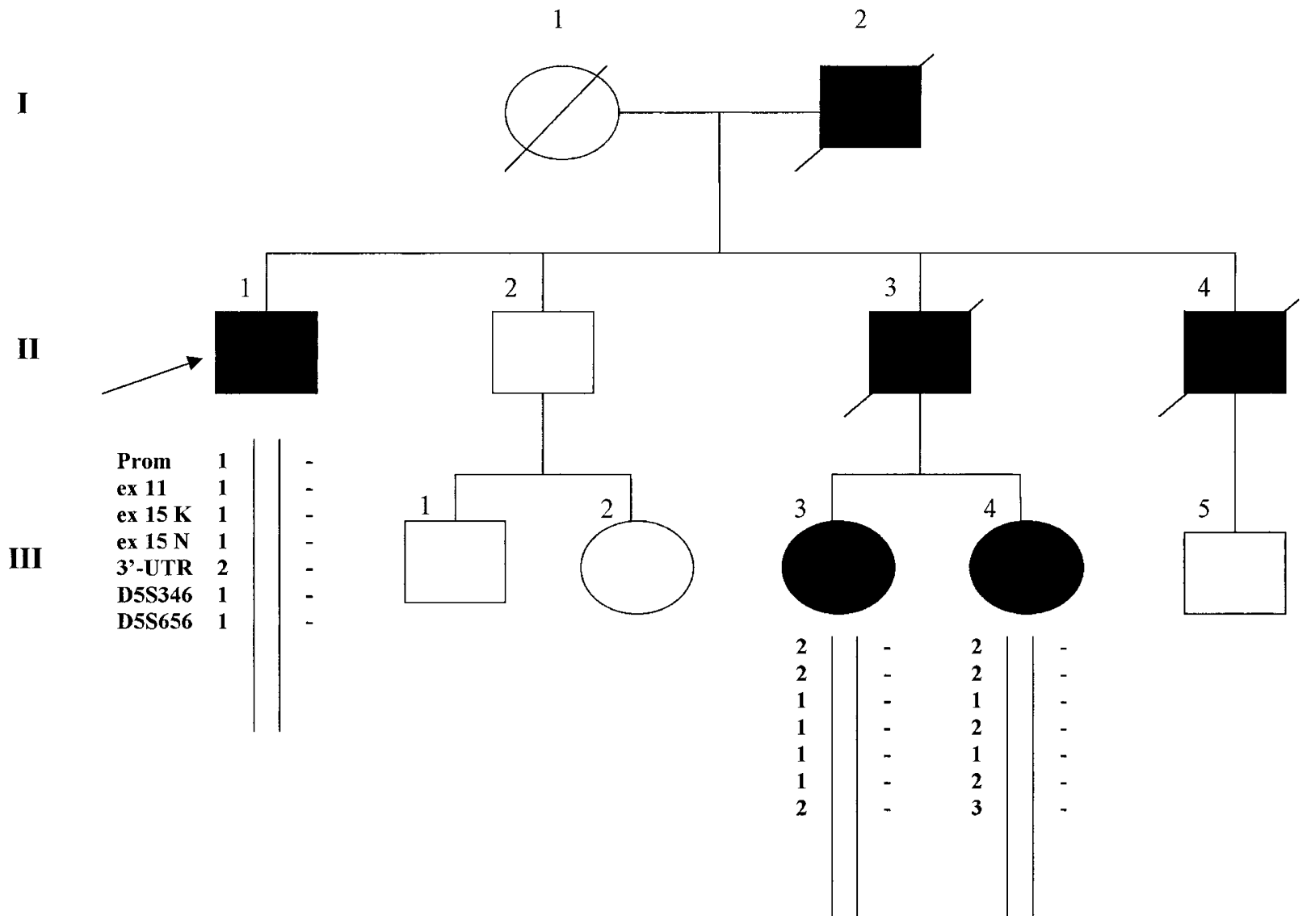

Figure 1.

Pedigree and haplotype analysis of Patient No. 1 (arrow). Filled symbols = clinically affected familial adenomatous polyposis individuals. Five intragenic markers, encompassing APC from the promoter to the 3'-UTR region, as well as two microsatellites at the 3 ' of the gene, have been investigated. The deleted polymorphic alleles are marked by a dash.

were detected in 18 APC mutation-negative FAP kindreds from Finland (Moisio et al, 2002). On the contrary, De Rosa et al (1999) reported gene deletions in three (33\%) of nine mutation-negative FAP families of Italian origin. Our study on Italian patients suggested gene deletion in 3 of 10 cases. Further studies are needed to more precisely evaluate $A P C$ deletion frequency in relation to the origin of patients.

Our panel of mutation negative cases also includes six subjects with normal (or slightly reduced) APC gene expression. Despite the mutation strategy we used, we could have missed gene alterations in these cases (20\% of all tested cases). Moisio et al (2002), by using a comprehensive mutation detection strategy, could not identify $A P C$ alterations in $28 \%$ of Finnish FAP kindreds, including deletions and imbalance in allelic expression.

In the light of the most recent findings (Al-Tassan et al, 2002; Jones et al, 2002; Sieber et al, 2003), mutation assessment of the $M Y H$ base-excisionrepair gene in $A P C$ alteration-negative patients might represent a relevant issue.

In conclusion, we have shown that constitutive $A P C$-reduced expression is present in a fraction of polyposis patients (4/10) with no detectable truncating mutations within the APC coding region. However, 6 of 30 patients with a clinical diagnosis of polyposis did not show evidence of $A P C$ mutation after intensive molecular screening. We can exclude that mutations of the CTNNB1 and $C D H 1$ genes play a significant role in FAP/AAPC predisposition.

\section{Materials and Methods}

\section{Patients}

Blood samples were obtained from 30 unrelated patients of Italian origin who were diagnosed with FAP or AAPC on the basis of family history and/or endoscopic assessment of colonic polyps. Adenomas were diagnosed and typed according to the World Health Organization criteria (Jass et al, 1990). Overall, 22 patients displayed more than 100 colorectal adenomas (classic FAP) and 8 patients displayed less than 100 adenomas (AAPC). The mean age at polyposis diagnosis was 31 (range, 16-42) years for classic FAP and 40 (range, 16-65) years for AAPC. All patients showed polyps throughout the entire colon; only one patient had extracolonic manifestations (osteomas). After informed consent, blood samples were obtained from one affected individual per family (from three affected subjects in one case) and used for DNA and RNA extraction. DNA and RNA were extracted from lymphocytes by using standard procedure and the Qlamp RNA Blood Mini Kit (Qiagen), respectively. 


\section{APC gene analysis}

PTT. Truncating mutations were investigated by PTT. PTT was performed using a set of primers that allow amplification of the entire cDNA (http://www.ncbi.nih.gov/genebank/; Accession Number M73548) into five overlapping fragments (Bala et al, 1996; van der Luijt et al, 1996a). Fragments 2 to 5 encompassing exon 15 were obtained by directly amplifying genomic DNA by means of Taq Extender (Stratagene). Fragment 1, encompassing exons 1 to 14, was obtained by RT-PCR using hexamer primers according to the First Strand Synthesis Kit procedure (Roche). PCR products were used for PTT. The PTT was performed using a TnT/T7 coupled reticulocyte lysate system (Promega). Translation products were loaded on a $14 \%$ Tris-glycine-SDS polyacrylamide gel (Bio-Rad). Samples showing a bandshift were reamplified by PCR and sequenced on an ALFexpress II Sequencer (Amersham Biosciences) by using the AutoLoad Solid Phase Sequencing kit (Amersham Biosciences). Results were analyzed by the ALFwin 2.00 program (Amersham Biosciences).

$E M D$. Base changes were investigated by the Passport Mutation Scanning Kit (Amersham Biosciences), an EMD system. This method, based on the recognition and cleavage of mismatches in duplex DNA molecules by T4 Endonuclease VII, allows mutation detection with approximately $100 \%$ sensitivity and 94\% specificity compared with the DNA direct sequencing method (Del Tito et al, 1998). Thirteen overlapping fragments (600-1200 bp) covering the entire $A P C$ coding region were amplified by PCR using Cy5 fluorescent-labeled primers (Table 3). Following the manufacturer's instructions, each fragment was hybridized with the corresponding wild-type sequence DNA and subjected to enzymatic cleavage by T4 Endonuclease VII. Cleavage fragments were analyzed on an ALFexpress II Sequencer by the ALFwin Fragment Analyser 1.0 Program (Amersham Biosciences).

Genotype Analysis. Genotypes were determined at seven different polymorphic markers encompassing the APC locus. The following five markers were SNPs intragenic to APC: rs 2019720, located in the promoter region; APC 1458, located within exon 11; APC 5037, located within exon 15K; FB54D, located within exon $15 \mathrm{~N}$; and $37 \mathrm{~A} / 37 \mathrm{~B}$, located within the 3 '-UTR. Patients were also genotyped for two microsatellite markers, D5S346 and D5S656, located at $32 \mathrm{~kb}$ and $628 \mathrm{~kb} 3$ 'of $A P C$, respectively. All selected SNPs were characterized by allele frequencies close to 0.50 . We amplified the polymorphic regions by using primers and PCR conditions as reported at the Genome Database

Table 3. Primers and PCR Conditions

APC and CTNNB1 primers and PCR conditions

\begin{tabular}{|c|c|c|}
\hline Exons/codons & Forward and reverse $\left(5^{\prime}>3^{\prime}\right)$ & $\begin{array}{l}\text { Annealing temperature } \\
\left({ }^{\circ} \mathrm{C}\right) / \text { amplimer size (bp) }\end{array}$ \\
\hline \multicolumn{3}{|l|}{$A P C$} \\
\hline 1-14/1-189 & GCTGCAGCTTCATATGATC and TGAGATTCTGAAGTTGAGCG & $56 / 581$ \\
\hline $1-14 / 159-344$ & CGCTCAACTTCAGAATCTCA and CAGACTGTCGCATGGATATAC & $57 / 575$ \\
\hline $1-14 / 340-529$ & CAAGACAGCTGTATATCCATGC and AAGTGCTCTCATGCAGCCTT & $57 / 566$ \\
\hline $1-14 / 516-709$ & AAGGCTACGCTATGCTCTATGA and GGTTCTTGAGCATGCTAACTG & $58 / 585$ \\
\hline 15/651-834 & CCACAGGCAAATCCTAAGAG and GGAGCTGGGTAACACTGTAG & $58 / 549$ \\
\hline 15/814-987 & TAATACTGGCAACATGACTGT and CTTACTTTCATCATCTTCAG & $58 / 519$ \\
\hline 15/981-1184 & CTCGATTGAATCCTATTCTGAAG and CTGTGATGATGAAGGAATATCTGT & $58 / 609$ \\
\hline 15/1183-1370 & TGCCACAGATATTCCTTCATC and TTGGGTGTCTGAGCACCACTTT & $60 / 561$ \\
\hline 15/1359-1618 & AAATCTCCCTCCAAAAGTGG and AGCATTTACTGCAGCTTGCT & $58 / 777$ \\
\hline 15/1470-1992 & CCTGTGGCAAGGAAACCAAGT and GGTTCTCCCTGTGAGTCAG & $58 / 1566$ \\
\hline 15/1959-2345 & CCAGTTTGCTTTTCTCATAATTCCT and CTAGGGGATGATGTCCTTGG & $58 / 1158$ \\
\hline $15 / 2321-2714$ & TACAGTCTCCTGGCCGAAACT and GATTTTCCAAACCCACGGTA & $60 / 1179$ \\
\hline 15/2493-2883 & TCTCTATCCACACATTCGTCTGTT and CTTCCAGAACAAAAACCCTCTAA & $69 / 1170$ \\
\hline \multicolumn{3}{|c|}{ 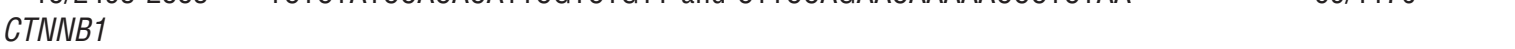 } \\
\hline $1-4 / 1-126$ & AAGCCTCTCGGTCTGTGG and TGATGGTTCAGCCAAACGCT & $60 / 600$ \\
\hline $4-7 / 112-316$ & CTGCTCATCATCCCACTAATGTC and TCCACCACTAGCCAGTATGA & $56 / 610$ \\
\hline $6-10 / 307-511$ & AGCAAGCTCATCATACTGGC and CGAATCAATCCAACAGTAGC & $56 / 614$ \\
\hline $9-14 / 497-703$ & ATCCCACTGGCCTCTGATAA and TCATCCTGGCGATATCCAAG & $56 / 617$ \\
\hline $13-16 / 688-885$ & GACTGCTGATCTTGGACTTG and GAGCTACTTCAAAGCAAGCAA & $56 / 611$ \\
\hline
\end{tabular}

APC oligonucleotides for real-time quantitative RT-PCR

\begin{tabular}{llc}
\hline Oligonucleotides & \multicolumn{1}{c}{ Sequences $\left(5^{\prime}>3^{\prime}\right)$} & Amplimer size (bp) \\
\hline Probe & ATTAGAGCGTCTTAAAGAGCTT & 88 \\
Forward primer & TTCCATAAGAACGGAGGGACA & \\
Reverse primer & TTTGACCGCAGTTTTTACTCCAGGGAAAATTACT & \\
\hline
\end{tabular}


(http://www.gdb.org) and at the NCBI-Single Nucleotide Polymorphism (http://www.ncbi.nlm.nih.gov/ SNP) web sites. SNPs were investigated by restriction enzyme digestion of PCR products: Rsal was used for markers rs 2019720 and APC 1458, Mspl for FB54D, and Sspl for T/C 3'-UTR. APC 5037 was investigated by direct sequencing.

Real-Time Quantitative RT- PCR. APC expression was assessed by monitoring the mRNA level. We used an assay based on the $5^{\prime}$ exonuclease activity of TaqDNA polymerase (Gibson et al, 1996; Holland et al, 1991). In addition to the standard PCR components, this assay requires an oligonucleotide probe specific to a sequence between two primers. The probe is labeled with two different fluorophores, a reporter dye at the $5^{\prime}$ end and a quencher dye at the $3^{\prime}$ end. Fluorescence emission from the reporter is absorbed by the quencher. During the extension phase of each PCR cycle, TaqDNA polymerase cleaves the probe annealed between the two primers. The cleavage, by separating the two dyes, enables detection of the reporter fluorescence. The resulting increase in reporter emission is directly proportional to the amount of product generated by each PCR cycle. We obtained APC cDNA by RT-PCR as described above. A cDNA fragment of $88 \mathrm{bp}$, covering the exon 2 to 3 juxtaposition, was used as a target for the assay (Table 3). A cDNA fragment from the GAPDH gene was used as an internal control (Applied Biosystems). APC and GAPDH probes were labeled at the $5^{\prime}$ ends with the reporter dyes FAM and JOE, respectively, and at the $3^{\prime}$ ends with the TAMRA quencher dye (Applied Biosystem). Both the APC primers and probe were designed by using PRIMER EXPRESS software (Applied Biosystems). Probe and primer sequences are listed in Table 3. Real-time quantitative RT-PCR was performed in 25 $\mu$ l containing $1 \times$ Taq Man Universal Master mix (Applied Biosystems). The optimal APC amplification conditions were as follows: $200 \mathrm{~nm}$ for the probe in the presence of $900 \mathrm{~nm}$ forward and $150 \mathrm{~nm}$ reverse primers. The optimal GAPDH amplification conditions were those suggested by the manufacturer (Applied Biosystems). Amplification reactions were performed for 2 minutes at $50^{\circ} \mathrm{C}$ and 10 minutes at $95^{\circ} \mathrm{C}$, followed by 40 cycles of denaturation at $95^{\circ} \mathrm{C}$ for 15 seconds and annealing at $60 \mathrm{C}^{\circ}$ for 1 minute. We performed two independent experiments. Each experiment comprised (in triplicate) control samples from 2 healthy individuals, samples from the 10 patients with undetectable $A P C$ mutations, and 2 no-template controls. The reporter emission was measured by an $A B I$ PRISM 7700 Sequence Detection System (Applied Biosystems): the signal is normalized to an internal reference and the software sets the threshold cycle $\left(\mathrm{C}_{\mathrm{T}}\right)$ when the reference becomes equal to 10 standard deviations of the baseline. We quantified the target $A P C$ cDNA by calculating the $2^{-\left(\Delta \Delta \mathrm{C}_{\mathrm{T}}\right)}$ value where $\Delta \Delta \mathrm{C}_{\mathrm{T}}=\Delta \mathrm{C}_{\mathrm{T} 1}\left(\mathrm{C}_{\mathrm{T}} A P C-\mathrm{C}_{\mathrm{T}} \mathrm{GAPDH}\right)-\Delta \mathrm{C}_{\mathrm{T} 2}\left(\mathrm{C}_{\mathrm{T}}\right.$ Calibrator $-\mathrm{C}_{\mathrm{T}} \mathrm{GAPDH}$ ). We used as a calibrator the sample with the lower $\mathrm{C}_{\mathrm{T}}$ value. We normalized the $2^{-\left(\Delta \Delta C_{T}\right)}$ mean value of each patient sample against the $2^{-\left(\Delta \Delta C_{T}\right)}$ mean value of the healthy control sub- jects. By this approach, samples normally expressing both alleles are expected to give values close to 1 , whereas samples expressing only one allele are expected to give values close to 0.5. Table 2 shows mean values from the two independent experiments.

\section{$\beta$-Catenin Gene (CTNNB1) Mutation Analysis}

The entire $\beta$-catenin cDNA was amplified into five fragments of $600 \mathrm{bp}$ each. Primers are reported in Table 3. The PCR fragment corresponding to the $5^{\prime}$ terminal region, including the complete GSK3 $\beta$ phosphorylation consensus motif, was analyzed by direct sequencing as described above. The other four PCR products, encompassing the 12 Armadillo repeats, were subjected to EMD as above.

\section{E-Cadherin Gene (CDH1) Mutation Analysis}

The 16 exons and part of the promoter region of the gene were amplified by PCR using the primers and reaction conditions reported by Berx et al (1995). PCR products were sequenced. Sequencing reactions were performed in forward and reverse by using the Big Dye Terminator Cycle Sequencing Ready Reaction Kit (PE) and analyzed on an ABI Prism 310 sequencer (PE).

\section{References}

Al-Tassan N, Chmiel NH, Maynard J, Fleming N, Livingston AL, Williams GT, Hodges AK, Davies DR, David SS, Sampson JR, and Cheadle JP (2002). Inherited variants of MYH associated with somatic G:C $\rightarrow$ T:A mutations in colorectal tumors. Nat Genet 30:227-232.

Bala S, Kraus C, Wijnen J, Meera Khan P, and Ballhausen WG (1996). Multiple products in the protein truncation test due to alternative splicing in the adenomatous polyposis coli (APC) gene. Hum Genet 98:528-533.

Becker KF, Atkinson MJ, Reich U, Becker I, Nekarda H, Siewert JR, and Hofler H (1994). E-cadherin gene mutations provide clues to diffuse type gastric carcinomas. Cancer Res 54:3845-3852.

Berx G, Staes K, van Hengel J, Molemans F, Bussemakers MJ, van Bokhoven A, and van Roy $F$ (1995). Cloning and characterization of the human invasion suppressor gene E-cadherin (CDH1). Genomics 26:281-289.

Cao X, Eu KW, Seow-Choen F, and Cheah PY (1999). Germline mutations are frequent in the APC gene but absent in the beta-catenin gene in familial adenomatous polyposis patients. Genes Chromosome Cancer 25:396-398.

De Rosa M, Scarano MI, Panariello L, Carlomagno N, Rossi GB, Tempesta A, Borgheresi P, Renda A, and Izzo P (1999). Three submicroscopic deletions at the APC locus and their rapid detection by quantitative-PCR analysis. Eur $\mathrm{J}$ Hum Genet 7:695-703.

Del Tito BJ Jr, Poff HE 3rd, Novotny MA, Cartledge DM, Walker RI 2nd, Earl CD, and Bailey AL (1998). Automated fluorescent analysis procedure for enzymatic mutation detection. Clin Chem 44:731-739. 
Dobbie Z and Muller H (1999). Germline mutations in the beta-catenin gene are not associated with the FAP phenotype without an APC mutation. J Med Genet 36:573-574.

Fodde R and Khan PM (1995). Genotype-phenotype correlations at the adenomatous polyposis coli (APC) gene. Crit Rev Oncog 6:291-303.

Friedl W, Meuschel S, Caspari R, Lamberti C, Krieger S, Sengteller M, and Propping P (1996). Attenuated familial adenomatous polyposis due to a mutation in the $3^{\prime}$ part of the APC gene: A clue for understanding the function of the APC protein. Hum Genet 97:579-584.

Gibson UE, Heid CA, and Williams PM (1996). A novel method for real time quantitative RT-PCR. Genome Res 6:995-1001.

Groden J, Thliveris A, Samowitz W, Carlson M, Gelbert L, Albertsen H, Joslyn G, Stevens J, Spirio L, Robertson M, Sargeant L, Krapcho K, Wolff E, Burt R, Hughes JP, Warrington J, McPherson J, Wasmuth J, Le Paslier D, Abderrahim H, Cohen D, Leppert M, and White R (1991). Identification and characterization of the familial adenomatous polyposis coli gene. Cell 66:589-600.

Guilford P, Hopkins J, Harraway J, McLeod M, McLeod N, Harawira P, Taite H, Scoular R, Miller A, and Reeve AE (1998). $\mathrm{E}$-cadherin germline mutations in familial gastric cancer. Nature 392:402-405.

He TC, Sparks AB, Rago C, Hermeking H, Zawel L, da Costa LT, Morin PJ, Vogelstein B, and Kinzler KW (1998). Identification of c-MYC as a target of the APC pathway. Science 281:1509-1512.

Heinimann K, Thompson A, Locher A, Furlanetto T, Bader E, Wolf A, Meier R, Walter K, Bauerfeind P, Marra G, Muller H, Foernzler D, and Dobbie Z (2001). Nontruncating APC germline mutations and mismatch repair deficiency play a minor role in APC mutation-negative polyposis. Cancer Res 61: 7616-7622.

Holland PM, Abramson RD, Watson R, and Gelfand DH (1991). Detection of specific polymerase chain reaction product by utilizing the $5^{\prime}-3^{\prime}$ exonuclease activity of Thermus aquaticus DNA polymerase. Proc Natl Acad Sci USA 88: $7276-7280$.

Jass JR, Sobin LH, and Watanabe H (1990). The World Health Organization's histologic classification of gastrointestinal tumors: A commentary on the second edition. Cancer 66:2162-2167.

Jones S, Emmerson P, Maynard J, Best JM, Jordan S, Williams GT, Sampson JR, and Cheadle JP (2002). Biallelic germline mutations in MYH predispose to multiple colorectal adenoma and somatic $\mathrm{G}: \mathrm{C} \rightarrow \mathrm{T}: \mathrm{A}$ mutations. Hum Mol Genet 11:2961-2967.

Kinzler KW, Nilbert MC, Su LK, Vogelstein B, Bryan TM, Levy DB, Smith KJ, Preisinger AC, Hedge P, McKechnie D, Finniear R, Markham A, Groffen J, Boguski MS, Altschul SF, Horii A, Ando H, Miyoshi Y, Miki Y, Nishisho I, and Nakamura $Y$ (1991). Identification of FAP locus genes from chromosome 5q21. Science 253:661-665.

Laken SJ, Papadopoulos N, Petersen GM, Gruber SB, Hamilton SR, Giardiello FM, Brensinger JD, Vogelstein B, and Kinzler KW (1999). Analysis of masked mutations in familial adenomatous polyposis. Proc Natl Acad Sci USA 96:23222326.
Lamlum H, Al Tassan N, Jaeger E, Frayling I, Sieber O, Reza FB, Eckert M, Rowan A, Barclay E, Atkin W, Williams C, Gilbert J, Cheadle J, Bell J, Houlston R, Bodmer W, Sampson $\mathrm{J}$, and Tomlinson I (2000). Germline APC variants in patients with multiple colorectal adenomas, with evidence for the particular importance of E1317Q. Hum Mol Genet 9:22152221.

Laurent-Puig P, Beroud C, and Soussi T (1998). APC gene: Database of germline and somatic mutations in human tumors and cell lines. Nucleic Acids Res 26:269-270.

Mandl M, Caspari R, Jauch A, Boker T, Raschke H, Sengteller M, Propping P, and Friedl W (1996). Familial adenomatous polyposis: A submicroscopic deletion at the APC locus in a family with mentally normal patients. Hum Genet 97:204-208.

Moisio AL, Jarvinen $H$, and Peltomaki P (2002). Genetic and clinical characterisation of familial adenomatous polyposis: A population based study. Gut 50:845-850.

Muller O, Nimmrich I, Finke U, Friedl W, and Hoffmann I (1998). A beta-catenin mutation in a sporadic colorectal tumor of the RER phenotype and absence of beta-catenin germline mutations in FAP patients. Genes Chromosome Cancer 22:37-41.

Munemitsu S, Albert I, Souza B, Rubinfeld B, and Polakis P (1995). Regulation of intracellular beta-catenin levels by the adenomatous polyposis coli (APC) tumor-suppressor protein. Proc Natl Acad Sci USA 92:3046-3050.

Orsulic S, Huber O, Aberle H, Arnold S, and Kemler R (1999). $\mathrm{E}$-cadherin binding prevents beta-catenin nuclear localization and beta-catenin/LEF-1-mediated transactivation. J Cell Sci 112:1237-1245.

Perry I, Hardy R, Tselepis C, and Jankowski JA (1999). Cadherin adhesion in the intestinal crypt regulates morphogenesis, mitogenesis, motogenesis, and metaplasia formation. Mol Pathol 52:166-168.

Pilarski RT, Brothman AR, Benn P, and Shulman Rosengren $S$ (1999). Attenuated familial adenomatous polyposis in a man with an interstitial deletion of chromosome arm $5 q$. Am J Med Genet 86:321-324.

Powell SM, Petersen GM, Krush AJ, Booker S, Jen J, Giardiello FM, Hamilton SR, Vogelstein B, and Kinzler KW (1993). Molecular diagnosis of familial adenomatous polyposis. N Engl J Med 329:1982-1987.

Rubinfeld B, Albert I, Porfiri E, Fiol C, Munemitsu S, and Polakis P (1996). Binding of GSK3beta to the APC-betacatenin complex and regulation of complex assembly. Science 272:1023-1026.

Samowitz WS, Powers MD, Spirio LN, Nollet F, van Roy F, and Slattery ML (1999). Beta-catenin mutations are more frequent in small colorectal adenomas than in larger adenomas and invasive carcinomas. Cancer Res 59:1442-1444.

Sieber OM, Lamlum H, Crabtree MD, Rowan AJ, Barclay E, Lipton L, Hodgson S, Thomas HJ, Neale K, Phillips RK, Farrington SM, Dunlop MG, Mueller HJ, Bisgaard ML, Bulow $\mathrm{S}$, Fidalgo $\mathrm{P}$, Albuquerque $\mathrm{C}$, Scarano $\mathrm{MI}$, Bodmer $\mathrm{W}$, Tomlinson IP, and Heinimann K (2002). Whole-gene APC deletions cause classical familial adenomatous polyposis, but not attenuated polyposis or "multiple" colorectal adenomas. Proc Natl Acad Sci USA 99:2954-2958.

Sieber OM, Lipton L, Crabtree M, Heinimann K, Fidalgo P, Phillips RK, Bisgaard ML, Orntoft TF, Aaltonen LA, Hodgson 
SV, Thomas HJ, and Tomlinson IP (2003). Multiple colorectal adenomas, classic adenomatous polyposis, and germ-line mutations in MYH. N Engl J Med 348:791-799.

Smits R, Ruiz P, Diaz-Cano S, Luz A, Jagmohan-Changur S, Breukel C, Birchmeier C, Birchmeier W, and Fodde R (2000). E-cadherin and adenomatous polyposis coli mutations are synergistic in intestinal tumor initiation in mice. Gastroenterology 119:1045-1053.

Spirio L, Olschwang S, Groden J, Robertson M, Samowitz W, Joslyn G, Gelbert L, Thliveris A, Carlson M, Otterud B, Lynch $\mathrm{H}$, Watson $\mathrm{P}$, Lynch $\mathrm{P}$, Laurent-Puig $\mathrm{P}$, Burt R, Hughes JP, Thomas G, Leppert M, and White R (1993). Alleles of the APC gene: An attenuated form of familial polyposis. Cell 75:951957.

Suriano G, Mulholland D, de Wever O, Ferreira P, Mateus AR, Bruyneel E, Nelson CC, Mareel MM, Yokota J, Huntsman D, and Seruca R (2003). The intracellular E-cadherin germline mutation V832M lacks the ability to mediate cell-cell adhesion and to suppress invasion. Oncogene 22:5716-5719.

Tetsu $O$ and McCormick F (1999). Beta-catenin regulates expression of cyclin D1 in colon carcinoma cells. Nature 398:422-426.

van de Wetering M, Barker N, Harkes IC, van der Heyden M, Dijk NJ, Hollestelle A, Klijn JGM, Clevers $H$, and Schutte M (2001). Mutant E-cadherin breast cancer cells do not display constitutive Wnt signaling. Cancer Res 61:278-284.

van der Luijt RB, Hogervorst FBL, Den Dunnen JT, Meera Khan P, and Van Ommen G-JB (1996a) In: Landegren U, editor. Laboratory protocols for mutation detection. New York: Oxford University Press, 140-151. van der Luijt RB, Meera Khan P, Vasen HF, Breukel C, Tops CM, Scott RJ, and Fodde R (1996b). Germline mutations in the 3' part of APC exon 15 do not result in truncated proteins and are associated with attenuated adenomatous polyposis coli. Hum Genet 98:727-734.

van der Luijt RB, Vasen HF, Tops CM, Breukel C, Fodde R, and Meera Khan P (1995). APC mutation in the alternatively spliced region of exon 9 associated with late onset familial adenomatous polyposis. Hum Genet 96:705-710.

Varesco L, Gismondi V, Presciuttini S, Groden J, Spirio L, Sala P, Rossetti C, De Benedetti L, Bafico A, Heouaine A, Grammatico P, Del Porto G, White R, Bertario L, and Ferrara GB (1994). Mutation in a splice-donor site of the APC gene in a family with polyposis and late age of colonic cancer death. Hum Genet 93:281-286.

Vasen HF (2000). Colorectal cancer and family history. Ann Chir Gynaecol 89:179-184.

Wong AST and Gumbiner BM (2003). Adhesion-independent mechanism for suppression of tumor cell invasion by E-cadherin. J Cell Biol 161:1191-1203.

Yan H, Dobbie Z, Gruber SB, Markowitz S, Romans K, Giardiello FM, Kinzler KW, and Vogelstein B (2002). Small changes in expression affect predisposition to tumorigenesis. Nat Genet 30:25-26. 